\title{
EL DEPARTAMENTO NACIONAL DEL TRABAJO Y SU RELACIÓN CON LA LEY DE ACCIDENTES LABORALES DE $1915^{1}$
}

THE NATIONAL DEPARTMENT OF LABOR AND ITS

RELATIONSHIP WITH THE LAW

OF LABOUR ACCIDENTS IN 1915

PABLO MADDALENA •

Pablo Maddalena es profesor de Historia y maestrando en Historia en el Instituto de Altos Estudios Sociales de

\section{Resumen}

El artículo recorre los debates sobre accidentes laborales que sostuvieron técnicos y políticos argentinos desde principios del siglo XX hasta la promulgación de la ley 9.688 en 1915 . Se analizan las ideas y saberes técnicos vinculados con la temática que se difundieron desde el Departamento Nacional del Trabajo, para analizar en qué medida actuaron como cimientos para la construcción de la política pública. Para ello se pone en diálogo las fuentes oficiales que otorgaron relevancia a los accidentes de trabajo y los proyectos legislativos que al respecto fueron impulsados desde divergentes sectores sociales y políticos. A su vez, se plantea el interrogante sobre si la ley produjo un giro novedoso al fijar mecanismos de resolución de litigios en casos de accidentes o por el contrario reafirmó prácticas establecidas previamente. Finalmente se discuten los argumentos que vinculan esta ley a un entramado legislativo proclive a resguardar los intereses de los trabajadores. la Universidad Nacional de San Martín (IDAES-UNSAM). e-mail: pdmaddalena@yahoo.com.ar.

\section{Summary}

The article reviews the discussions on labor accidents sustained by experts and politicians in Argentina since the early twentieth century until the promulgation of the Work Accidents and Occupational Diseases Act, $n^{\circ}$ 9.688, in 1915. The analysis focuses on the ideas and technical knowledge related to work accidents that were transmitted from the National Department of Labour, and its impact in the building of a public policy. Possible dialogues between official sources on work accidents and the legislative projects proposed by diverse social and political sectors are suggested. Consecutively, arise the question as to whether the legislative enactment of 1915 implemented a novel legal framework when setting dispute resolution mechanisms in case of accident, or otherwise, reasserted practices prior to the norm. This approach calls into question the relation of Act 9.688 with a legislative background prone to safeguarding workers' best interests.

\footnotetext{
${ }^{1}$ Agradezco los valiosos comentarios de María Paula Luciani, Karina Ramacciotti, Ludmila Scheinkman, Cristiana Schettini y Andrés Stagnaro. También agradezco las observaciones de los evaluadores anónimos de la revista.
} 